TEME, г. XLI, бр. 2, април - јун 2017, стр. 489-502

Оригинални научни рад

DOI: $10.22190 /$ TEME1702489A

Примљено: 2. 12. 2016.

UDK 005.334:658.286

Одобрено за штампу: 15. 6. 2017.

\title{
ANALYSIS OF FACTORS OF DISRUPTIONS/INTERRUPTIONS IN UPSTREAM SUPPLY CHAIN AND THEIR INFLUENCE ON VULNERABILITY
}

\author{
Aleksandra Anđelković*, Nada Barac, Marija Radosavljević \\ University of Niš, Faculty of Economics, Niš, Serbia \\ *aleksandra_caka@yahoo.com
}

\begin{abstract}
In the modern business environment risk management has become a key assistant to enterprise management. Considering that, supply chain management, as part of enterprise management, cannot ignore the risks and the need for implementation of an adequate risk management strategy. Supply chain, as well as inter-organizational network, is the source of competitive advantage. However, inadequate risk management within a supply chain can lead to interruptions of the chain and to the lack of results at the level of the whole supply chain, as well as at the level of individual partners. Upstream supply chain represents the part of supply chain from suppliers to producer. The objective of this paper is to analyse how and to what extent the structure and the number of partners in this part of the supply chain influence (increase or decrease) supply chain vulnerability. The authors analyse the factors which most commonly affect to upstream supply chain and threaten its functioning. By analysing the supply chains from different area, the authors suggest that the size of the supplier's base can be treated as the resistance factor, but also as a factor of vulnerability.
\end{abstract}

Key words: $\quad$ vulnerability, risk, factors, upstream, supply chain.

\section{РАЊИВОСТ И ФАКТОРИ ПРЕКИДА/ПОРЕМЕЋАЈА У UPSTREAM ЛАНЦУ СНАБДЕВАЊА}

\section{Апстракт}

У савременом пословном окружењу управљање ризицима постало је кључни асистент менаџмента. С тим у вези, управљање ланцима снабдевања, као део менаџмента, не може да игнорише ризике и потребу за применом адекватне стратегије управљања ризицима. Ланац снабдевања, као интерорганизациона мрежа, извор је конкурентске предности. Међутим, неадекватно управљање ризицима у ланцу снабдевања може довести до прекида ланца и изостанка резултата како на нивоу ланца тако на нивоу појединачних партнера. Upstream ланац снабдевања представља део ланца од добављача до произвођача. Циљ рада је да анализира како и у којој мери структура и број партнера у овом делу ланца снабдевања утичу (повећавају га или смањују) на рањивост ланца. Аутори анализирају факторе који 
најчешће погађају upstream ланац снабдевања и угрожавају његово функционисање. Анализом ланаца снабдевања из различитих области аутори указују на то да се величина снабдевачке базе може третирати као фактор отпорности, али и као фактор рањивости.

Кључне речи: рањивост, ризик, фактори, upstream, ланац снабдевања.

\section{INTRODUCTION}

Risk management has become an integral part of every business. A great number of companies are not ready for uncertain events ${ }^{1}$, which are result of supply disruptions, delays in the execution of logistics activities, inadequate security and similar (Mahendran et al., 2011, p. 836). Compared to traditional business, supply chain managers are faced with a great number of risk factors (Barac, Anđelković-Pešić, Anđelković, 2013, 242). In most cases, appearance of these factors is a consequence of the process of globalization and outsourcing. Before intensifying these processes, some types of risk factors such as currency fluctuations, social instability, and even natural disasters were considered as local or regional events. However, by developing international trade, disruptions are getting a global character. Besides new risk factors, one of the trends the global supply chains are facing concerns rapid expanding risks through the supply network. This trend is the result of continuous increasing of the supply chain efficiency. Just-in-Time, as well as a reduced supply base, decreasing the possibility for amortization of supply chain disruptions and interruptions (Behdani et al., 2012). These trends influence faster and easier spreading of the risk through the supply chain. In case of risk events, companies do not have enough available resources and alternatives for action. Focus on lean approach in business has eliminated a great number of buffers, such as stocks of raw materials/finished products, employees, a lot of sources of supply and etc. In this way, lean business can cause delays due to bottlenecks, which are the results of eliminating buffers, and jeopardize the whole supply chain (Barac et al., 2013, p. 309). In addition, by outsourcing activities, a great number of companies are losing control over resources. Insufficient control over the activities and transparency consequently affect the company's ability to detect distortions and create a true picture of the environment (Behdani, 2013, p. 7). This situation creates the need for risk management in the supply chain.

\footnotetext{
${ }^{1}$ Knight gives the following explanation: "If you are not sure that something will happen, but you know that there are chances that this happens" it's a risk, however, "if you do not know what the chances are that something happens" that is uncertainty (Peck, 2010, 198).
} 
Supply chain risk management involves integration of companies with the aim of minimizing the risks and likelihood of their occurrence, by developing cooperative relationships, efficient business processes and a high level of information exchange (Handfield et al., 2008, p. 30). Therefore, the lack of an integrated approach into supply chain is a key obstacle in the implementation of supply chain risk management. It involves company-level risk management (risk management at the level of individual companies), supply chain-level risk management or risk management upstream and downstream in the supply chain and environment-level risk management (Briano et al., 2010, p. 138). Each level requires a detailed risk analysis and management. In the focus of the authors of the paper are only the problems that concern risks in the upstream supply chain, i.e. from the producer (manufacture) to all suppliers.

Upstream supply chain risks include actual and potential disruptions within the flow of raw materials, between suppliers and manufacturers. Upstream supply chain risks are often associated with the inability of suppliers to respond effectively to the manufacturer's requirements. Suppliers have a problem with delays in delivery, delivery of raw materials in inadequate quantities and poor quality. Consequences of upstream risks could be delays in production, lack of profits of the supply chain, as well as dissatisfaction and loss of manufacturer's confidence. Disruptions and interruptions in the upstream supply chain are the result of the selection of inadequate suppling strategy and/or suppliers that don't have available capacity for responding to manufacturer's requests. In this way base of suppliers does not have possibility to provide continuity in the supply chain. The appearance of disruptions and interruptions through the material's flows or upstream risks are intensifying with increasing a number of outsourcing components and reduction of supplier base.

Stockwhip effect could be defined as a domino effect of the unavailability of parts or components from suppliers that affect the customers from the downstream supply chain and their sales activities and operational planning. This effect could be defined as a limitation or disruption of the upstream supply chain, which causes disruptions in the downstream supply chain. Partners in the supply chain need to eliminate immediately such sources of supply and/or find an alternative (Jeeva, 2011, p. 739). A supply base limited to one source is acceptable only with developing collaborative relationships between partners in the upstream supply chain. Quality usually is the thing that is missing in the absence of collaborative relationships. Suppliers tend to minimize their costs and thus jeopardize the results of the whole supply chain (Christopher, 2011, p. 215) in the sense of quality. In addition, decision about selection of a single source of supply has proved as very risky in practice. Some examples are: Ericsson and Philips in 2000, when a fire in the company Philips brought to stop the production of Ericsson and loss from \$ 400 million; Due to a problem with a mechanism to lock the 
doors, Ford in 1998 had a delay in the production of 3 days, which caused damage amounting to 100 million euros; Toyota in 1997 suffered damage in the amount of $\$ 300$ million due to a fire at the plant Aisin, which was affiliated with the Toyota Just-in-Time System (Blome, \& Henke, 2009, p. 130).

In theory, there are considerable disagreements on this issue. There is a group of authors, (Sheffi, \& Rice, 2005; Christopher, 2011) which put the emphasis on one source of supply as a way of reducing risk, but, on the other hand, authors (Behdani, 2013; Blome, \& Henke, 2009; Handfield, $\&$ Nichols, 2002) who emphasize the importance of supply from a number of sources point out the need to reduce excessive dependence from suppliers, which is often cited as the primary cause of the risk of supply from a single source. However, although one source of supply undoubtedly increases the degree of dependency, a greater dependence does not mean higher upstream risk, at the same time. In any case, the decision in relation to one or more sources of supply must be based on the possibility of dependence between the partners. The larger number of sources of supply may also cause disruptions in the upstream supply chain. The consequence of dividing demand on a greater number of suppliers may reduce interest of these suppliers for innovating. In situations where there is a change in manufacturer's requests, suppliers will first respond to the requirements of its key customers. This strategy of supplying could have a lower level of service and flexibility, in comparison to the case of supplying from one source. The conclusion is that less dependency does not necessarily have to be associated with a lower upstream risk.

\section{RESEARCH METHODOLOGY}

In order to test theoretical views and conclusions, the authors of the paper conducted empirical research, in terms of risk factors which act in the upstream supply chain. Companies that participated in the survey were selected from the list of hundred most successful companies in the Republic of Serbia, according to the achieved revenue. In addition, questionnaires were sent just to the companies that belong to the food industry, automotive industry and chemical industries. These industries are the best representatives of different logistics systems considering inbound and outbound flows of raw materials and goods, and they are the best examples for analysing the influence of risk factors in the upstream supply chain (Barac, Milovanović, 2006, 30). The survey was conducted from July to October 2015. The analysed sample consists of 30 companies. All companies belong to the group of large enterprises, according to the categorization of the Business Registers Agency. The sample includes 11 companies from the food industry, as well as from the automotive industry, while there are 8 returned questionnaires from companies in the chemical 
industry. The aims of the conducted research are: identification of risk factors in the upstream supply chain, consideration of risk factors in the supply chains from different industries, assessment of the importance of the supplier's base in supply chains from different industries, in terms of increasing resilience and reducing vulnerability. In this regard, the following hypotheses have been defined:

H1: The importance of individual disruptions/interruptions factors, in terms of the consequences on a supply chain, is different between the chains from different industries;

H2: The size of the supplier's base is a factor of disruptions/ interruptions in the upstream supply chains;

H3: The structure of the supplier's base, in terms of partner's size, affects vulnerability of the supply chain.

In the data collection process, the company's managers were evaluated on the importance of risk factors, by the Likert scale, where 1 indicates that a factor has negligible effect on the upstream supply chain, while mark 5 indicates that factor can cause serious consequences in the upstream supply chain. By analysing the results, one can assess not only the risk factor with the significant consequences on the supply chain (according to the managers' opinion) but also the group of the factors that supply chains from different industries are usually exposed to. In addition, testing of the hypotheses requires the collection of the data about the impact of the supplier's base size on disruptions/interruptions in the supply chain, as well as about supplier's base structure, in terms of the relation of number of small and medium-sized enterprises and large companies. In order to test the hypothesis, besides descriptive statistics, the authors used the Chi-square test, through the SPSS program for processing of the data.

\section{RESULTS AND DISCUSSION}

In the research process 19 different risk factors in the upstream supply chain have been identified. Those 19 factors belong to different environments (Christopher, \& Peck, 2004, p. 9), some of them belong to the group of external supply chain factors (it is difficult to control these factors because they occur outside the supply chain), while others belong to the group of internal factors of the supply chain and internal factors of the company (it is easier to predict these factors because they occur inside the supply chain). Descriptive statistics was used to describe the basic perceptions of managers about the consequences of each factor.

In that sense, Table 1 shows the results for each factor of disruptions/ interruptions at the whole sample level, for all 30 companies. The highest mean value is that of the factor Volatility of market and exchange rate $($ mean $=3.4333)$. Thus, according to the surveyed managers the greatest consequences for the supply chain provokes the aforementioned factor. The 
highest level of disagreement among managers could be seen in the factor Reduction of production capacity (standard deviation $=1.47936$ ). However, the answer to the first hypotheses requires analysing descriptive statistics' results for all risk factors at the level of each industry. In this sense, food industry can expect the greatest consequences form the factor One (less) source of supply (mean $=3.7273$ ), while there is the largest disagreement about the consequences from the factor Great number of sources of supply without of trust (standard deviation $=1.90215)$.

Table 1 Descriptive statistics - The importance of the risk factors

\begin{tabular}{|c|c|c|c|c|c|c|c|c|}
\hline \multirow{2}{*}{$\begin{array}{l}\text { Risk } \\
\text { factors }\end{array}$} & \multicolumn{2}{|c|}{$N=30$} & \multicolumn{2}{|c|}{$\begin{array}{l}\text { Food industry } \\
\qquad \mathrm{N}=11\end{array}$} & \multicolumn{2}{|c|}{$\begin{array}{c}\text { Automotive } \\
\text { industry } \\
\mathrm{N}=11\end{array}$} & \multicolumn{2}{|c|}{$\begin{array}{c}\text { Chemical } \\
\text { industry } \mathrm{N}=8\end{array}$} \\
\hline & Mean & $\begin{array}{c}\text { Std. } \\
\text { Deviation }\end{array}$ & Mean & $\begin{array}{c}\text { Std. } \\
\text { Deviation }\end{array}$ & Mean & $\begin{array}{c}\text { Std. } \\
\text { Deviation }\end{array}$ & Mean & $\begin{array}{c}\text { Std. } \\
\text { Deviation }\end{array}$ \\
\hline $1^{2}$ & 2.3333 & 1.32179 & 2.2727 & 1.48936 & 1.9091 & 1.04447 & 3.0000 & 1.30931 \\
\hline 2 & 1.1333 & .34575 & 1.3636 & .50452 & 1.0000 & 0.00000 & 1.0000 & 0.00000 \\
\hline 3 & 1.9333 & .73968 & 1.8182 & 60302 & 1.4545 & .52223 & 2.7500 & .46291 \\
\hline 4 & 3.4333 & .97143 & 3.3636 & 80904 & 3.9091 & 1.04447 & 2.8750 & .83452 \\
\hline 5 & 2.4000 & .96847 & 2.7273 & 1.10371 & 2.5455 & .93420 & 1.7500 & .46291 \\
\hline 6 & 2.6000 & .96847 & 3.0909 & 1.04447 & 2.1818 & .40452 & 2.5000 & 1.19523 \\
\hline 7 & 2.7000 & 1.36836 & 3.7273 & 1.27208 & 2.3636 & 1.12006 & 1.7500 & 88641 \\
\hline 8 & 3.0000 & .78784 & 3.1818 & .87386 & 3.1818 & .40452 & 2.5000 & .92582 \\
\hline 9 & 3.2333 & 1.22287 & 3.5455 & 1.43970 & 3.2727 & 1.19087 & 2.7500 & .88641 \\
\hline 10 & 2.0667 & 1.43679 & 2.7273 & 1.90215 & 1.8182 & 1.16775 & 1.5000 & .53452 \\
\hline 11 & 2.3333 & .99424 & 2.2727 & .90453 & 2.6364 & .80904 & 2.0000 & 1.30931 \\
\hline 12 & 2.8000 & 1.03057 & 2.5455 & .93420 & 3.0909 & 1.04447 & 2.7500 & 1.16496 \\
\hline 13 & 2.2000 & 1.09545 & 2.8182 & 1.16775 & 1.5455 & .52223 & 2.2500 & 1.16496 \\
\hline 14 & 1.2667 & .58329 & 1.0909 & .30151 & 1.6364 & .80904 & 1.0000 & 0.00000 \\
\hline 15 & 1.6333 & .85029 & 1.8182 & .75076 & 1.5455 & .93420 & 1.5000 & .92582 \\
\hline 16 & 2.1667 & .94989 & 2.9091 & .94388 & 1.9091 & .70065 & 1.5000 & .53452 \\
\hline 17 & 2.8000 & 1.29721 & 2.4545 & .93420 & 3.3636 & 1.12006 & 2.5000 & 1.77281 \\
\hline 18 & 2.5667 & 1.38174 & 2.4545 & .82020 & 2.7273 & 1.61808 & 2.5000 & 1.77281 \\
\hline 19 & 2.4667 & 1.47936 & 2.0909 & 1.13618 & 3.0000 & 1.54919 & 2.2500 & 1.75255 \\
\hline
\end{tabular}

Source: Authors' calculation

\footnotetext{
2 (1) - Natural disasters (floods, fires, storms, earthquakes); (2) - Terrorism; (3) - Political instability and wars; (4) - Volatility of market and exchange rate, (5) - Ports and customs strikes; (6) - Limiting legislation; (7) - One (less) source of supply; (8) - Poor raw materials quality; (9) - Delays and damage in the delivery of raw materials/goods; (10) Great number of sources of supply without of trust; (11) - Low transparency among partners; (12) - Inadequate demand assessment (inability to answer the requirements/ surplus inventories); (13) - Interruptions of business processes; (14) - Strikes of employees; (15) - Poor quality of products; (16) - Wrong application of policies, rules and procedures; (17) - Failures on machinery and information technology; (18) - Lead time variability; (19) - Reduction of production capacity
} 
Automotive industry has the greatest problem with the factor Volatility of the market and exchange rate (mean $=3.9091$ ), while the highest standard deviation has the factor Lead time variability (1.61808). Finally, the chemical industry recorded the greatest consequences from the factor Natural disasters (floods, fires, storms, earthquakes), since mean is equal 3, while the while there are the largest disagreement about the consequences from the factors Failures on machinery and information technology and Lead time variability (standard deviation $=1.77281$ ).

According to the results of descriptive statistics it is obvious that the factors with the greatest consequences for the supply chain are quite different among the analysed industries. In this regard, it could be concluded that the first hypothesis is confirmed. Companies from the food industry have the greatest consequences from internal risks of the supply chain, as well as the companies from the automotive industry, while the companies from the chemical industry have the greatest consequences from external risks of the supply chain. The first hypothesis may be tested by the analysis of variance - ANOVA test. In this case additional hypotheses should be formulated as it follows:

$\mathrm{H}_{0}$ : There is no difference in the importance of individual disruptions/ interruptions factors, between the chains from different industries, and

H1: There is a difference in the importance of individual disruptions/ interruptions factors, between the chains from different industries.

Although the analysis of variance usually is conducted for the characteristics measured on an interval scale or on a relationship scale, modelled after Gravetter F., Wallnau L., (2004), Statistics for the Behavioral Sciences, Thomson, Wadsworth, where the analysis of variance is applied in psychological research results (for the subjective assessment of the situation of individual patients after different treatments), the application of this statistical tool is considered to be reasonable in this case, too.

Table 2 Test of Homogeneity of Variances

\begin{tabular}{cccc}
\hline Levene Statistic & df1 & df2 & Sig. \\
\hline .713 & 2 & 54 & .495 \\
\hline \multicolumn{5}{c}{ Source: Authors' calculation }
\end{tabular}

The test of homogeneity of variances (Table 2) shows that Sig. is higher than 0.05, meaning that in further calculation the Bonferroni method should be used. The analysis of variance (Table 3) shows that there is no statistical significance of the differences between the tested samples (Sig. $>0.05$ ), so with result Sig. $=0.227$ null hypothesis $\left(\mathrm{H}_{0}\right)$ is accepted. 
Table 3 Analysis of variance

\begin{tabular}{lccccc}
\hline & $\begin{array}{c}\text { Sum of } \\
\text { Squares }\end{array}$ & df & $\begin{array}{c}\text { Mean } \\
\text { Square }\end{array}$ & F & Sig. \\
\hline Between Groups & 1.551 & 2 & .775 & 1,526 & .227 \\
Within Groups & 27.433 & 54 & .508 & & \\
\hline Total & 28.984 & 56 & & \\
\hline \multicolumn{5}{c}{ Source: Authors' calculation }
\end{tabular}

In order to confirm this result, multiple comparisons have been performed. Table 4 shows whether there is a statistical significance of the differences between separate samples (from different industries). The results indicate that between separate samples there are no statistically significant differences, since the results of the comparisons between the samples show significance higher than 0.05 . So according to this analysis null hypothesis should be accepted, too. Therefore, the final decision concerning the first hypotheses of this research is to reject the first hypotheses.

Table 4 Multiple comparisons

\begin{tabular}{|c|c|c|c|c|c|c|}
\hline \multirow{2}{*}{\multicolumn{2}{|c|}{$\begin{array}{l}\text { VAR00004 } \\
\text { (I) }\end{array}$}} & \multirow{2}{*}{$\begin{array}{c}\text { Mean } \\
\text { Difference } \\
(\mathrm{I}-\mathrm{J})\end{array}$} & \multirow{2}{*}{$\begin{array}{l}\text { Std. } \\
\text { Error }\end{array}$} & \multirow[t]{2}{*}{ Sig. } & \multicolumn{2}{|c|}{ 95\% Confidence Interval } \\
\hline & & & & & Lower & Upper \\
\hline \multirow[t]{2}{*}{1.00} & 2.00 & .16684 & .23125 & 1.000 & -.4045 & 7382 \\
\hline & 3.00 & .40211 & .23125 & .263 & -.1693 & .9735 \\
\hline \multirow[t]{2}{*}{2.00} & 1.00 & -.16684 & .23125 & 1.000 & -.7382 & .4045 \\
\hline & 3.00 & .23526 & .23125 & .941 & -.3361 & .8066 \\
\hline \multirow[t]{2}{*}{3.00} & 1.00 & -.40211 & .23125 & .263 & -.9735 & .1693 \\
\hline & 2.00 & -.23526 & .23125 & .941 & -.8066 & .3361 \\
\hline
\end{tabular}

The second hypothesis imposes an analysis of the relation between the number of partners, as a factor of disruptions/interruptions, and the number of disruptions/interruptions, as an indicator of the supply chain vulnerability. Table 5 shows the relation between those two variables. Based on the parameters and numerical data in the table, it couldn't be clearly noticed that there is connection between the observed variables. For this reason and with the purpose to determine the relation between the analysed variables, the Chi-Square test, as a non-parametric test, is considered as appropriate for the following analysis. 
Table 5 Ratio of the number of interruptions and number of partners

\begin{tabular}{llcccccc}
\hline & & \multicolumn{7}{c}{ Number of interruptions } & \\
\cline { 3 - 7 } & & 0 & $1-5$ & $6-10$ & $11-20$ & 21 and more & Total \\
\hline \multirow{2}{*}{$\begin{array}{l}\text { Number } \\
\text { of partners }\end{array}$} & $0-50$ & 6 & 4 & 4 & 0 & 1 & 15 \\
& $51-100$ & 1 & 1 & 0 & 0 & 0 & 2 \\
\cline { 3 - 7 } Total & 101 and more & 6 & 2 & 3 & 2 & 0 & 13 \\
\hline
\end{tabular}

Based on the analysis of the results in Table 6, it is obvious that there is no statistically significant connection between the tested variables. Specifically, the value of the $p$-test is greater than 0.05 , which means that between the tested variables there is no dependence, or, also, that the number of partners in the supply chain does not influence its vulnerability, i.e. the number of disruptions/interruptions.

Table 6 Chi-Square Tests

\begin{tabular}{lrcc}
\hline & Value & df & Asymp. Sig. (2-sided) \\
\hline Pearson Chi-Square & $5.270^{\mathrm{a}}$ & 8 & .728 \\
Likelihood Ratio & 6.742 & 8 & .565 \\
Linear-by-Linear Association & .000 & 1 & .991 \\
N of Valid Cases & 30 & & \\
\hline
\end{tabular}

${ }^{\mathrm{a}} 13$ cells $(86.7 \%)$ have expected count less than 5 .

The minimum expected count is .07 .

The same hypothesis may be tested at the industry level, in order to gain more precise results and to see whether this hypothesis cannot be accepted for all three industries. In this way one could be able to determine if the number of partners in the upstream supply chain, as an independent variable, is the factor of risk and vulnerability of the supply chain, separately for each industry. In this sense, Table 7 (where the same non-parametric test has been used) shows a relation and dependence of vulnerability from the number of partners in the upstream supply chain in the automotive industry. The analysis of the results for the companies from the food and chemical industries shows that the $p$-value is greater than 0.05 , which means that between the tested variables there is no connection. In addition, the confirmation of the second hypotheses for automotive industry could be justified by the fact that supply chains from the automotive industry are the most complex in terms of the number and structure of partners (Thun, Drüke, \& Hoenig, 2011, p. 5511), and, in this respect, in the automotive industry there is a connection between the analysed variables. 
Table 7 Chi-Square Tests by industries

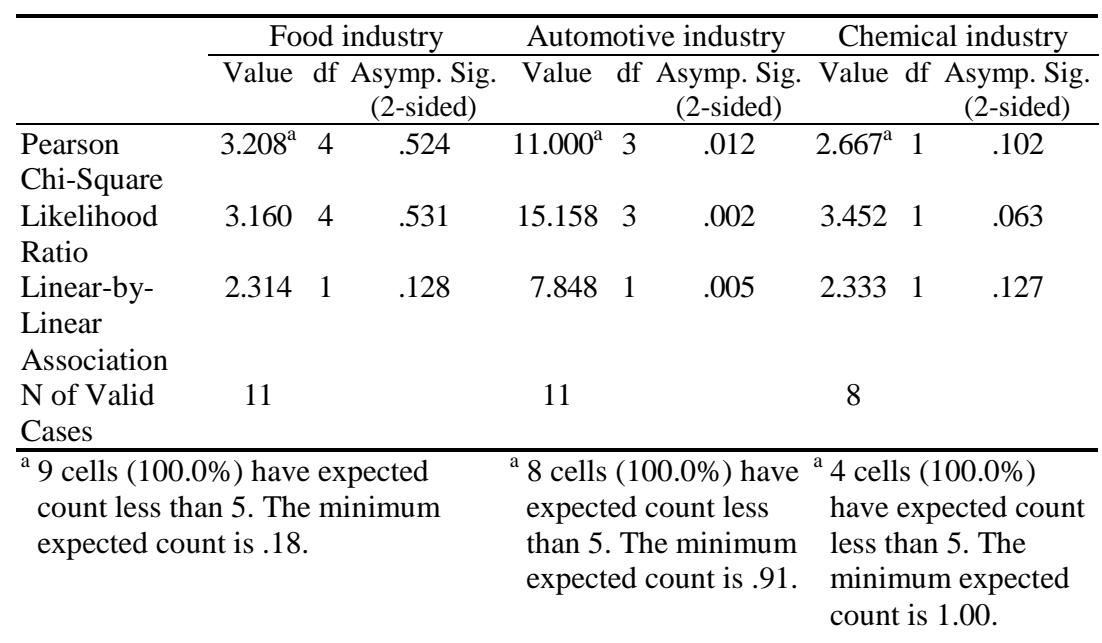

By analysing the relation between the level of vulnerability, measured by the number of disruptions/interruptions in the supply chain, and the structure of the partners in the supply chain, in terms of the number of small and medium-sized and large companies, it has been noticed that there is a correlation between those variables. The $p$-value of 0.015 , in Table 8 , confirms the third hypotheses, about the existence of dependence between the variables, number of disruptions/interruptions and partner's structure. High level of vulnerability is present in those supply chains where small and medium-sized enterprises are dominated.

Table 8. The Chi-Square Tests of partners' structure

\begin{tabular}{lrrc}
\hline & Value & df & Asymp. Sig. (2-sided) \\
\hline Pearson Chi-Square & $12.308^{\mathrm{a}}$ & 4 & .015 \\
Likelihood Ratio & 12.809 & 4 & .012 \\
Linear-by-Linear Association & 2.074 & 1 & .150 \\
N of Valid Cases & 30 & & \\
\hline
\end{tabular}

a. 7 cells $(70.0 \%)$ have expected count less than 5 .

The minimum expected count is .23 .

The results from Table 8 could be explained by the fact that small and medium-sized companies do not have enough resources, material or immaterial, to counter uncertain and risky events (Finch, 2004; Zwißler, \& Hermann, 2012). In this way, this group of partners becomes an important factor of vulnerability of the entire supply chain (Hennet, Mercantini, \& Demongodin, 2008, p. 256). This certainly does not mean that such partners should be avoided, but it is necessary to help them build an adequate risk management strategy in the supply chain. 


\section{CONCLUSION}

The initiators of the supply chain creation come from two sources: 1) the external pressures and 2) the potential benefits of the strategic supply chain. External pressures includes constant improvement of technology, growing demand across national borders, requirements for lower costs with satisfying different needs, intensifying competition among the supply chains. On the other side, a greater competitive advantage comes from the interweaving of knowledge and other resources that are the result of linking partners through the supply chain (Halley, 2001, p. 15). Thus, even if they are a source of vulnerability, as demonstrated by results of the research, small and medium-sized enterprises in the supply chain could be sources of a number of competences, especially for the activities for which they are specialized. This is another reason why it is impossible to eliminate the small and medium enterprises from the supply chain.

The hypothesis about the impact of the number of partners in the upstream supply chain was confirmed only in those companies that belong to the automotive industry. The result of research shows that the supply base in the supply chain may be, but does not have to be a factor of disruptions/interruptions of the supply chain. In industries that do not have a great number of suppliers of second, third or higher order, as is the case with the food and chemical industry, managers do not recognize the size of the supplier's base as a factor of vulnerability. However, supply chains from the automotive industry, as well as supply chains from airline and electronics industry (Thun, Drüke, \& Hoenig, 2011, 5511), have a great number of higher order suppliers. In the aforementioned industries it is possible that manufacturers in the supply chain do not have direct communication with the suppliers of higher orders or, even, they are not familiar with their partners at all.

For example, more than $90 \%$ of Hewlett-Packard's (HP) products are the result of manufacturing of their partners, which points to the fact that those partners are responsible for the produced quality. The problem of the HP's supply chain are the suppliers of the second order. Unlike direct or first degree suppliers, suppliers of the second order do not have contractual relationships with HP and HP does not have direct contact with them. Increasing the number of the second order suppliers could have a negative impact for the value of the entire supply chain. The main reason for this claim is that the second order suppliers often do not have to follow all the procedures of a common management system (Barac, Andjelković, 2012, p. 39).

The confirmation of the second hypotheses about the existence of relation between the size of the supplier's base and supply chain vulnerability only for companies from the automotive industry could be explained by the fact that the automotive industry belongs to the system of logistics with strong input flows. Therefore, the upstream segment in the automotive 
industry is very important and with great influence on the whole supply chain. Other two groups of companies belong to the system of logistics with strong output flows (chemical industry) and balanced flows (the food industry). Such differences between the companies from different industries show that it is necessary to define an adequate supply chain risk management strategy, adapted to the specific industry.

\section{REFERENCES}

Barac, N., \& Anđelković, A. (2012).Application of AHP method in partner's selection process for supply chain development. Industrija, 40(2), 35-50.

Barac, N., Anđelković-Pešić, M., Milovanović, G., \& Anđelković, A. (2013). Supply Chain Resilience: New Source of Competitive Advantage. In: Marinković, S. (Ed.): International conference The Global Economic Crisis and the Future of European Integration (pp. 307-315). Niš, University of Nis, Faculty of Economics.

Барац, Н., Анђелковић-Пешић, М., Анђелковић, А. (2013). Анализа односа међу учесницима ланца снабдевања у југоисточној Србији [Analysis of the Relationships Between Supply Chain Participants in Southeastern Serbia], Теме - часопис за друштвене науке: Конкурентност привреде и светска економска криза, 37(1), 241-256.

Барац, Н., Миловановић, Г. (2006), Стратегијски менаџмент логистике [Strategic logistics management], СКЦ, Ниш.

Behdani, B. (2013). Handling Disruptions in Supply Chains: An Integrated Framework and an Agent-based Model (Doctoral dissertation) Sharif University of Technology, Birjand, Iran. Retrieved from http://repository.tudelft.nl/islandora/ object/uuid:6f5e8db3-c1b7-4b2d-8035-3ae37a617564/?collection=research

Behdani, B., Adhitya, A., Lukszo, Z., \& Srinivasan, R. (2012). How to Handle Disruptions in Supply Chains - An Integrated Framework and a Review of Literature. Retrieved from http://papers.ssrn.com/sol3/papers.cfm?abstract_id= 2114201

Blome, C., \& Henke, M. (2009). Single versus Multiple Sourcing: A Supply Risk. In Zsidisin, G., \& Ritchie, B. (Eds.), Supply Chain Risk: A Handbook of Assessment, Management, and Performance (pp. 125-136). Springer.

Briano, E., Caballini, C., Giribone, P., \& Revetria, R. (2010). Objectives and perspectives for improving resiliency in Supply Chains. WSEAS Transactions on Systems, 9(2), 136-145.

Christopher, M. (2011). Logistics \& Supply Chain Management, Prentice Hall.

Christopher, M., \& Peck, H. (2004). Building the Resilient Supply Chain. International Journal of Logistics Management, 15(2), 1-13.

Finch, P. (2004). Case Study: Supply chain risk management. Supply Chain Management: An International Journal, 9(2), 183-196.

Gravetter F., \& Wallnau L., (2004). Statistics for the Behavioral Sciences, Thomson, Wadsworth.

Halley, A. (2001). Supply Chain Management and Development of Competencies: The Learning Logistics Concept and Applications. An International Journal Supply Chain Forum, 2(2), 12-19.

Handfield, R. B., \& Nichols, E. L. (2002). Supply Chain Redesign: Transforming Supply Chains into Integrated Value System, Prentice Hall. 
Handfield, R. B., Blackhurst, J., Elkins, D., \& Craighead, Ch. W. (2008). A Framework for Reducing the Impact of Disruptions to the Supply Chain: Observations from Multiple Executives. In Handfield, R. B., \& McCormack, K. (Eds.), Supply Chain Risk Management: Minimizing Disruptions in Global Sourcing (pp. 29-50). Taylor \& Francis Group.

Hennet, J. C., Mercantini, J. M., \& Demongodin, I. (2008). Toward an integration of risk analysis in supply chain assessment. $20^{\text {th }}$ European Modelling and Simulation Symposium, Simulation in Industry, EMSS '08 (pp. 255-260). Campora San Giovanni, Amantea (CS), Italy.

Jeeva, A. (2011). Reducing Supply Risk Caused by the Stock Whip Effect in Supply Chains. Proceedings of the 2011 International Conference on Industrial Engineering and Operations Management (pp. 739-744). Kuala Lumpur, Malaysia.

Mahendran, H., Narasimhan, K., Nagarajan, N., \& Gopinath, S. (2011). Investigation of Supply Chain Risk in the Indian Pharmaceutical Industry: A Case Study. Proceedings of the World Congress on Engineering 2011, Vol. I (pp. 836-841). London, U.K.

Peck, H. (2010). Supply Chain Vulnerability, Risk and Resilience. In Waters, D. (Ed.) Global Logistics: New Directions in Supply Chain Management, (pp. 192-207), Kogan Page.

Sheffi, Y., \& Rice, J. B. (2005). A Supply Chain View of the Resilience Enterprises. MITSloan Management Review, 47(1), 41-48.

Thun, J. H., Drüke, M., \& Hoenig, D. (2011). Managing uncertainty - an empirical analysis of supply chain risk management in small and medium sized enterprises. International Journal of Production Research, 49(15), 5511-5525.

Zwißler, F., \& Hermann, M. (2012). Supply Chain Risk Management in the Electronics Industry. In Emblemsvåg, J. (Ed.) Risk Management for the Future - Theory and Cases, (pp. 467-496). InTech, Croatia.

\title{
РАЊИВОСТ И ФАКТОРИ ПРЕКИДА/ПОРЕМЕһАЈА У UPSTREAM ЛАНЦУ СНАБДЕВАЊА
}

\author{
Александра Анђелковић, Нада Барац, Марија Радосављевић \\ Универзитет у Нишу, Економски факултет, Ниш, Србија
}

\section{Резиме}

Стварање и задржавање конкурентске предности и тржишног учешћа ограничено је факторима из окружења, без обзира на то да ли се ради о интерном или екстерном окружењу. Ланци снабдевања и партнери који га чине не би смели да дозволе себи да игноришу деловање тих фактора и динамично окружење. Суочавање са факторима поремећаја и/или прекида неизбежно је у савременим условима. Препознавање и уочавање ових фактора, као и њихових последица, постаје кључно за континуитет у пословању како појединачних предузећа тако и читавих ланаца снабдевања.

Није могуће израдити неки општи оквир за праћење фактора ризика у свим ситуацијама и за све ланце снабдевања, из разлога што се интензитет и фреквенција тих фактора значајно разликује код различитих грана индустрије. Такође, перцепције менаџера о последицама деловања ризичних фактора прилично се 
разликују код различитих индустрија. Факторе чије деловање доводи до озбиљних последица попут поремећаја или чак и прекида ланаца снабдевања потребно је на време препознати и избећи или ублажити њихово деловање.

У upstream ланцу снабдевања један од кључних фактора поремећаја и/или прекида је величина и структура снабдевачка база. Од координације у иpstream ланцу снабдевања зависиће испуњавање захтева крајњим потрошачима. Према томе, дефинисање адекватне снабдевачке базе је императив сваком ланцу снабдевања. У индустријама које су пример система логистике са јаким улазним током (такав случај присутан је у аутомобилској, авио, електронској индустрији и слично) снабдевачка база је значајно разграната. Због великог броја добављача, код оваквих индустрија снабдевачка база је често узрок бројних поремећаја и/или прекида, посебно ако са добављачима нису изграђени односи поверења. Код индустрија које су пример логистике са јаким излазним током или балансираним током снабдевачка база се често не препознаје као фактор ризика. У првом случају, сложеније је управљати downstream токовима због резултата у виду великог броја различитих готових производа. У другом пак случају постоји потпуна равноправност у погледу сложености управљања upstream и downstream токовима, те се величина и структура снабдевачке базе не препознају као фактори ризика. 